\title{
Elementary School Physical Education and Sport in Integrated Curriculum
}

\author{
Banu Setyo Adi \\ Faculty of Education \\ Yogyakarta State University \\ Yogyakarta, Indonesia \\ banu_adi@uny.ac.id
}

\begin{abstract}
Physical Education and Sport (PES) teachers in Indonesian. The 2013 Curriculum is entirely different from the 2006 curriculum. The basic difference is the are learning model and their achievements. In the 2013 curriculum, the teachers used integrated method at each grade level in the elementary school. The goal of this method was for the students to receive materials holistically. All the subjects were integrated into themes, subthemes, and Learning from 1 to 6 . The success of learning are affective, cognitive, and psychomotor skills. Physical Education and Sport (PES) is one of the subjects in the 2013 curriculum that is integrated. In the 2006 curriculum, the PES teachers prepared learning utilities independently, because the activities depended on Competency and Basic Competence. It was not integrated with another subject. In the 2013 curriculum, the PES teachers collaborated with the classroom teachers to prepare learning devices. This helped the learners to receive other subject matters. There are several ways to separate the materials from the theme. One of such ways is, that the need for collaboration helps to prepare the learning devices between the classroom teachers and the PES teachers. Another way is by encouraging the classroom teachers and PES teachers to attend conferences.
\end{abstract}

\section{Keywords-curriculum, physical education, integrated}

\section{INTRODUCTION}

The world has undergone many changes. This changes has its own challenges. The impact of education on the world has given rise to a new paradigm on the demands of skills that people must master. The demands of skills to be mastered in the $21^{\text {st }}$ century include student personalization, collaboration skills, communication skills, and information-gathering abilities. Productivity and creativity are core competencies and learning skills that aid in the development of student skills.

The Government of Indonesia has advised all citizens to get educated. This is contained in article 31 of the 1945 constitution. Education in Indonesia has been designed to fulfill all human resource skills. Educational curriculum in Indonesia keeps changing over time. The curriculum was established before independence and has been changed severally since then, 1947, 1952, 1964, 1968, 1975, 1984 (CBSA), 1994, 2004 (KBK), 2006 (KTSP), and 2013 (KTSP development). the curriculum in Indonesia is the same in other countries, the national education standard (SNP) was developed in other to guarantee quality education. Some of the reasons for the development of the Curriculum in 2013 are as follows: (1) Changes in the learning process and the assessment process requires additional hours of study, (2) The tendency of many countries to add more hours to their lesson periods, (3) Comparison with other countries indicates that the lessons learned in Indonesia is relatively short compared to other countries. In the 2013 curriculum, thematic learning was used to make all subjects into one theme. The recommended approaches are the scientific approach, Project base learning, problem base learning, and Inquiry. The scientific approach consists of, the observing stages (for identifying or finding problems), formulating problems, proposing or formulating hypotheses, collecting data by various techniques, analyzing data, drawing conclusions and communicating concepts, laws or principles that are "discovered. Problem base learning is defined as the beginning of dealing with the reality of life and society [7]. Based on the above opinion, the learning problem starts in learning the problems that actually occurs in the environment.

Physical education sports and health (PES) is one of the subjects taught in school. As one of the subjects, PES is part of the educational components on content standards and is aimed at supporting the national education objectives. At school, the allocation of lessons is 4 hours per week. it is assumed that 2 hours is used for field practices , 2 hours for theory or 3 hours for field practices and 1 hour for theory. . However, based on an interview dated January 23, 2018, most PES teachers use the lesson period for field practices and the theory is taught after every field practices. This is certainly not in accordance with what should be in the curriculum. The learning process that is carried out during the field practices also applies a scientific approach. However, no scientific approach has been identified that matches the character of PES. Meanwhile, based on interviews with some PES teachers and supervisors, PES is seen as a less important lesson. This certainly causes some problems that must be reflected upon by PES teachers. Based on the above background, the problems that arises are: 1) finding out if the purpose of PES is to develop affective, cognitive, and psychomotor span? What is the main emphasis of the domain and why ?;2) identifying the curriculum model used in K13 PES SD ?; 3) to what extent has the PES teacher's gone in their preparation in implementing K13? This essence of the paper is to examine the position of PES in the 2013 curriculum and its implementation.

\section{IMPLEMENTATION OF AN INTEGRATED CURRICULUM IN 2013}

The curriculum appraisal focuses on character-planting for basic education. According to Robin Forgaty the curriculum model consist of ten integrated learning models, namely: cellular, connected, nested, sequenced, shared, webbed, threaded, integrated, immersed, and networked. But, all ten models was not implemented in the 2013 curriculum. The webbed and integrated model is the model adopted in learning. 
the webbed model is a model that uses a thematic approach. It is characterized by the development of the curriculum using the theme approach and the teacher prepares the theme, as illustrated below is:

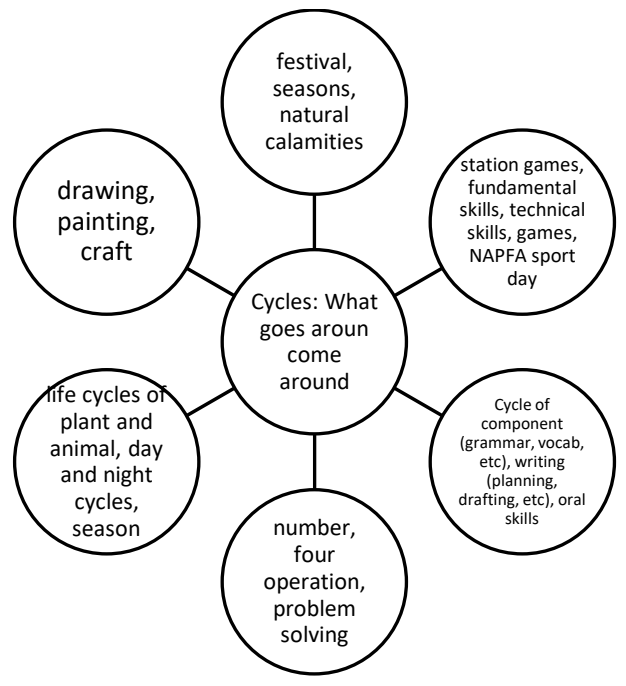

Fig. 1. The development of Curriculum

This model shows that PES can be integrated with the subjects incorporated in the theme. This model is usually used in primary schools. The second model is an interdisciplinary approach. In this model, the teacher tries to integrate some of the ideas or standards of competence into some of the subjects. An illustration of this model can be seen below.

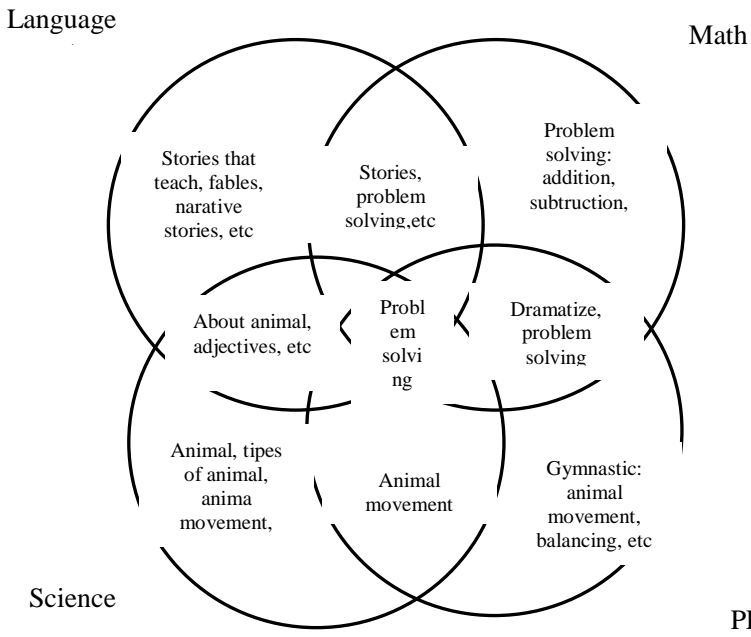

Fig. 2. The PES integrated models

Based on the picture of the integrated model above, PES can be integrated with other subjects. The application of this model is more in line with the middle-class. Permendikbud number 81a 2013 attachment iv describes the scientific approach in 5 stages: a) Observe; b) Ask; c) Collect information; d) Associate; and e) Communicate. The five main stages are classified under various learning activities as listed in the table below:
TABLE I. FIVE MAIN STAGE OF SCIENTIFIC APPROACH

\begin{tabular}{|c|c|c|}
\hline $\begin{array}{l}\text { Learning } \\
\text { Steps }\end{array}$ & $\begin{array}{l}\text { Learning } \\
\text { Activities }\end{array}$ & Competencies Developed \\
\hline Observe & $\begin{array}{l}\text { Reading, } \\
\text { Listening, Caring, } \\
\text { Looking (without } \\
\text { or with the tools) }\end{array}$ & $\begin{array}{l}\text { Training sincerity, accuracy, } \\
\text { look for informations }\end{array}$ \\
\hline Asking & $\begin{array}{l}\text { Asking questions } \\
\text { about the } \\
\text { informations that } \\
\text { isn't understood } \\
\text { from anything } \\
\text { observed or } \\
\text { questions to get } \\
\text { more informations } \\
\text { about anything } \\
\text { which has been } \\
\text { observed (started } \\
\text { by factual } \\
\text { question till } \\
\text { hypothetis } \\
\text { questions) }\end{array}$ & $\begin{array}{l}\text { Develop creativities, } \\
\text { curiosity, ability to formulate } \\
\text { questions to form critical } \\
\text { thinking which needed for } \\
\text { smart live dan study } \\
\text { throughout life }\end{array}$ \\
\hline $\begin{array}{l}\text { Collect } \\
\text { Informations/ex } \\
\text { periments }\end{array}$ & $\begin{array}{l}\text { - Do eksperiments } \\
\text { - Read other } \\
\text { sources beside } \\
\text { text books } \\
\text { - Observe the } \\
\text { objects/ case/ } \\
\text { - activities } \\
\text { - interview with } \\
\text { interviewees }\end{array}$ & $\begin{array}{l}\text { Develop accuracy attitude, } \\
\text { honest, polite, respect with } \\
\text { other opinion from someone } \\
\text { else, communications ability, } \\
\text { apply ability about collect } \\
\text { informations many ways has } \\
\text { been learned, develop } \\
\text { learning habit and learning } \\
\text { throughout life. }\end{array}$ \\
\hline Associate & $\begin{array}{l}\text { - Process } \\
\text { information has } \\
\text { been collected } \\
\text { from the result of } \\
\text { activities/experim } \\
\text { ents or the result } \\
\text { of observe } \\
\text { activities and } \\
\text { activities of } \\
\text { information's } \\
\text { collect. } \\
\text { - Information's } \\
\text { process has been } \\
\text { collected has } \\
\text { character to add } \\
\text { breadth and depth } \\
\text { till process } \\
\text { information which } \\
\text { have character to } \\
\text { look for solutions } \\
\text { from many } \\
\text { sources that have } \\
\text { other opinions till } \\
\text { with contradict. }\end{array}$ & $\begin{array}{l}\text { Develop honest attitude, } \\
\text { accuracy, and discipline; obey } \\
\text { the rules, hard work, ability to } \\
\text { apply the procedure and } \\
\text { ability to think inductively } \\
\text { and deductively in } \\
\text { concluding. }\end{array}$ \\
\hline Communicate & $\begin{array}{l}\text { Delivering the } \\
\text { result of } \\
\text { observations, } \\
\text { conclusion based } \\
\text { on the result of } \\
\text { analysis by oral, } \\
\text { written or other } \\
\text { media }\end{array}$ & $\begin{array}{l}\text { Develop honest attitude, } \\
\text { accuracy, and tolerance, } \\
\text { ability to think systematically, } \\
\text { brief, clear, and develop } \\
\text { ability to speak well and right } \\
\text { when tell the opinions. }\end{array}$ \\
\hline
\end{tabular}

\section{PES INSTRUCTIONAL MODELS IN INTEGRATED CURRICULA}

Physical education is an element of educational curriculum that is basically concerned with physical activities, designed and structured systematically, to stimulate growth and development, improve ability and skills , intelligence and character formation, instill positive values and attitudes in individuals in order to achieve the objectives of the education 
[1]. Physical education as an education content that uses a comprehensive but physically active approach that involves teaching social, cognitive, and physical skills, and achieving other goals through movement [6]. NASPE 1986 explains that a physically educated individual: 1 . performs a variety of physical activities; 2 . is physically fit; 3 . participates regularly in physical activities; 4 . knows the implications and benefits of physical activities and 5. The values of physical activities and its contribution to a healthy lifestyle [4]. Based on the above definitions, PES can be defined as an educational content that uses a physically activate approach to teaches social, cognitive, and physical skills and achievement of goals through motion. PES lessons involves all kinds of physical activities, physical fitness, the applications, benefits and values of physical activities and its contributions to a healthy lifestyle. The benefits of PES are not only related to the psychomotor domain, they are also related to other aspects. This is confirmed in the research results that there is a small but significant relationship between academic achievement in the field of mathematics and reading, and this is influenced by physical activity for about 70-300 minutes per week [2]. Cardiorespiratory and weight loss fitness is associated with academic achievement [8]. The physical activity is essential for the brain and learning barriers [3]. There is a positive relationship between physical activity and academic performance, especially in terms of concentration, memory and behavior in the classroom [9]. Based on the above opinion, physical activities in PES has a role in other spheres. Many models can be used in physical education lessons, such as: 1). Direct Instruction; this is characterized by teachercentered learning and the teachers directly provide materials to the learners. The teacher prepares all forms of play, desired goals, and coordinates learning activities [5]. In this model the teacher is the controller during the learning periods. The first priority in this model is psychomotor, the second priority is cognitive, and the third priority is affective; 2) Cooperative learning; is a learning model that is based on four main theories namely motivation, cognitive, social learning, and innate attitudes [5]. This model creates a situation in order to achieve group success; 3) Inquiry Teaching; is a learning model where students need to understand the process before they can express their knowledge about the physical activities [5]. The teacher first provides the answer and then tries to seek the opinions the students and then gives the students time to practice the answers; 4) Tactical Games is a learning model that attracts students to a game, teaches them to understand the game, and expects them to participate in the game with the knowledge they have acquired of the game [5]. Peer teaching is a learning model that involves the students teaching themselves, in other words students who have better understanding and ability are given the opportunity to help other students. This model can be used, if the teachers prepare some of the students as tutors before the activity starts . This model can only be practiced by high-class students, from the third grade to the sixth grade. The role of the teacher is providing assistances and encouragement (supporter), supervising tasks including all tasks related to the discipline of the child.. These tasks are concerned with improving the growth and development of the children.

\section{DISCUSSION}

The role of PES teachers in the implementation of the 2013 curriculum needs to be reinforced. The application of thematic learning model in elementary school requires the PES teachers to be creative. However, the limited socialization of the government on this curriculum has caused teachers to become confused in its application. It is understandable, because the lack of socialization from the government either in the form of training or mentorship, has caused most of the teachers to use the old curriculum for the learning process. As a result of lack of socialization and assistance, PES teachers should try to develop themselves through the activities of teacher KKG routine. During the introduction of learning tools, PES teachers should collaborate with the classroom teachers to map out themes for the specific subject pedagogy. The effect of the collaboration with the classroom teachers, facilitates the application of thematic learning that is currently being applied.

\section{CONCLUSION}

The 2013 curriculum suggests thematic learning for elementary school. This method is in accordance with the students whose mindsets are still holistic. The application of thematic learning should be used by PES teachers. PES teachers are also advised to collaborate with the classroom teachers in mapping out basic competencies. Therefore, the learning process of PES and other subjects are integrated. All these could be properly achieved if the existing forums are utilized.

\section{REFERENCES}

[1] Aip Sarifudin dan Muhadi. 1992.Pendidikan Jasmani dan Kesehatan. Jakarta: Departemen Pendidikan dan Kebudayaan Direktorat Jenderal Pendidikan Tinggi

[2] Carlson Susan A., et all .2008. Physical Education and Academic Achievement in lementary School: Data From the Early Childhood Longitudinal Study. American Journal of Public Health April 2008, Vol 98, No. 4 I. S. Jacobs and C. P. Bean, "Fine particles, thin films and exchange anisotropy," in Magnetism, vol. III, G. T. Rado and H. Suhl, Eds. New York: Academic, 1963, pp. 271-350.

[3] Cardinal BJ .2016. Physical Activity Education's Contributions to Public Health and Interdisciplinary Studies: Documenting More than Individual Health Benefits. Journal of Physical Education, Recreation, and Dance, Apr 2016; 87; 4; R. Nicole, "Title of paper with only first word capitalized," J. Name Stand. Abbrev., in press.

[4] Lounsbery Monica A.F. dan McKenzie Thomas L. 2015. Physically literate and physically educated: A rose by any other name?. Journal of Sport and Health Science 4 (2015) 139e144.

[5] Metzler, Michael W. 2005. Instructionaal Model physical education. Arizoa: Holcomb Hathaway, Publishier

[6] Kohl Harold W. III and Heather D. Cook. 2013.Educating the Student Body: Taking Physical Activity and Physical Education to School. NW Washington, DC: THE NATIONAL ACADEMIES PRESS.

[7] Poikela Esa and Anna Raija Nummenmaa. 2006. Understanding Problem-Based Learning. Finland: Tampere University Press

[8] Sardinha et all (2014) Fitness, fatness, and academic performance in seventh grade elementary school student. BMC Pediatric 14: 176

[9] Trudeau François and Roy J. Shephard .2008.Physical education, school physical activity, chool sports and academic performance. International Journal of Behavioral Nutrition and hysical Activity. 